\title{
Host-Pathogen Interactions in Douglas-Fir Seedlings Infected by Phellinus sulphurascens
}

\author{
R. N. Sturrock, M. A. Islam, and A. K. M. Ekramoddoullah
}

Natural Resources Canada, Canadian Forest Service, Pacific Forestry Centre, 506 West Burnside Road, Victoria, BC, V8Z 1M5, Canada. Accepted for publication 15 May 2007.

\begin{abstract}
Sturrock, R. N., Islam, M. A., and Ekramoddoullah, A. K. M. 2007. Hostpathogen interactions in Douglas-fir seedlings infected by Phellinus sulphurascens. Phytopathology 97:1406-1414.

Several aspects of the host-pathogen interaction between Douglas-fir (Pseudotsuga menziesii) and the fungal pathogen Phellinus sulphurascens were investigated in an in vitro inoculation system using young seedlings and fungal mycelia. Light microscopy confirmed that $P$. sulphurascens mycelia can successfully penetrate host epidermal cells within 3 days postinoculation (dpi). Extensive fungal colonization and cortical cell decay occurred within 14 dpi. Western immunoblot studies showed significant upregulation (five to sixfold) of four specific pathogenesis-related (PR) proteins in infected roots. These proteins were a Douglas-fir thaumatin-like protein (PmTLP), an endochitinase protein (ECP), a Douglas-

occurred at 12 dpi, whereas accumulations of the ECP and DF-PR10 proteins peaked at $7 \mathrm{dpi}$. For both inoculated and control Douglas-fir seedlings, only one of the four PR proteins, PmAMP1, was clearly detectable in needles. Immunolocalization experiments using fluorescein isothiocyanate-conjugated secondary antibodies confirmed accumulation of all four PR proteins mainly in and around cell walls of root cortical tissues. Overall, the highest immunofluorescence was observed in infected roots at $12 \mathrm{dpi}$, whereas labeling in control roots was negligible at all sample times. The ECP produced the highest fluorescence; the DF-PR10 the lowest. Upregulation and localization of these PR proteins in cortical tissues of inoculated roots suggest that they play a defensive role in response to infection by $P$. sulphurascens. This in vitro inoculation system will facilitate further proteomic and genomic studies of this important pathosystem.
\end{abstract} fir PR10 (DF-PR10) protein (PsemI), and a 10.6-kDa antimicrobial peptide (PmAMP1). The highest accumulation of PmTLP and PmAMP1

In western North America, Douglas-fir (Pseudotsuga menziesii sp. menziesii [Mirb.] Franco) is the most economically important conifer species affected by laminated root rot (LRR), a disease caused by the fungus Phellinus sulphurascens Pilát (syn. P. weirii (Murrill) Gilb. $(46,58,67)$. Productivity in forested stands, especially those dominated by Douglas-fir, can be significantly reduced wherever this pathogen occurs $(35,67,68)$.

Roots and stumps infected with $P$. sulphurascens can serve as viable inoculum sources for decades $(12,34)$. The fungus transfers at points of contact between infected and noninfected roots and grows along the surface of susceptible host roots as ectotrophic mycelia. The mycelia eventually penetrate both intact and injured bark to reach cambial and wood tissues, where the fungus causes decay. It has been suggested that the rapid ectotrophic spread of $P$. sulphurascens, which can advance considerably beyond the limits of internal decay, enables it to find and use existing infection courts such as bark abrasions, wounds, and small diameter feeder roots $(65,70,71)$. P sulphurascens that is growing rapidly on root bark, likely accompanied by numerous simultaneous penetrations, is also believed to be more effective in overcoming host resistance than are mycelia that are confined to the wood $(29,71)$.

As is the case for several other root disease fungi affecting conifers, little is known about the infection process of $P$. sulphurascens. Initial infection of mature Douglas-fir root bark by $P$. sulphurascens and other fungal pathogens is often indicated by the formation of a necrophylactic periderm (NP), or where NP formation fails to take place, by the browning of tissues in advance of infection $(31,55,61,62)$. A study of mature Douglas-fir

Corresponding author: R. N. Sturrock; E-mail address: rsturrock@pfc.cfs.nrcan.gc.ca

doi:10.1094/PHYTO-97-11-1406

(C) 2007, Her Majesty the Queen in right of Canada, Natural Resources Canada, Canadian Forest Service
Additional keywords: laminated root rot.

roots inoculated with $P$. sulphurascens showed NP formation can occur as soon as 2 months following inoculation (65). This same study saw occurrence of traumatic resin ducts in xylem tissues and evidence of callusing in response to $P$. sulphurascens infection. Unfortunately, mature conifer roots and tissues do not readily lend themselves to detailed, stepwise studies of host-pathogen interactions.

The accumulation of pathogenesis-related (PR) proteins is an integral component of the defense response of many host plants to pathogen infection (69). Immunolocalization of PR and similar proteins has previously been demonstrated in many cultivated crops $(3,16,30,33,40,44,47,50,56)$. However, relatively few studies have documented immunolocalization of PR and related proteins in conifers. Asiegbu et al. $(5,6,8,9)$ reported increased amounts of chitinase, $\beta$-1,3-glucanase and peroxidase in the cortical and endodermal tissues of pathogen-infected Norway spruce roots. Nahálková et al. (57) reported immunolocalization of a chitinbinding lectin protein in juvenile tissues of Pinus nigra Arn. seedlings during infection by two necrotrophic root pathogens, Heterobasidion annosum (Fr.) Bref. and Fusarium avenaceum (Corda ex Fries) Sacc.

Several PR proteins have also been shown to be upregulated in mature Douglas-fir roots in response to $P$. sulphurascens infection. These include PmTLP, a thaumatin-like protein found in Douglas-fir (76); an endochitinase protein (ECP; 62); and PsemI, a PR10 protein found in Douglas-fir (25). The PR5 family of proteins, which includes thaumatin-like proteins, has been isolated from many plant species. These proteins are generally of low molecular weight (under $35 \mathrm{kDa}$ ) and can be found sequestered in vacuoles or in intercellular washing fluids (76). PR5 proteins have antifungal activity in vitro and although the precise mechanism of action is not clear, it is believed to involve an increase in fungal membrane permeability $(1,60)$. The PmTLP occurring in Douglasfir is easily extracted from the apoplastic fluid of needles of 
P. sulphurascens-infected Douglas-fir and its synthesis in mature roots is known to be induced by fungal infection (76). The ECP found in Douglas-fir is heavily concentrated in the apoplastic fluid of both roots and needles of $P$. sulphurascens-infected trees. Its enzymatic activity as a chitinase has been confirmed, and Nterminal sequence analysis of this ECP shows it to have strong homology with acidic, endo-type chitinases (77). Endochitinases hydrolyze chitin, a $\beta-1,4-N$-acetyl-D-glucosamine polymer that is an important structural component of fungal cell walls. These chitinases work from within each polymer rather than its terminus (32). Chitinases have been associated with defense response in Douglas-fir to fungal attack because they hydrolyze chitin (77). Data collected by Ekramoddoullah et al. (25) confirmed that PsemI belongs to the PR10 family of proteins and that it shows a possible trend to upregulation in roots of mature Douglas-fir in response to infection by $P$. sulphurascens. PR10 proteins are small, primarily acidic, intracellular proteins (51). Many biotic stresses have been shown to activate the accumulation of PR10 proteins, suggesting their importance during plant defense responses (36). Polyclonal antibodies to each of PmTLP, ECP, and PsemI have been produced $(25,62,75)$. These antibodies will facilitate both inductive and immunohistological investigations of Douglas-fir and possibly other coniferous tissues challenged with forest root pathogens like $P$. sulphurascens.

The importance and practicality of studying host-pathogen interactions using conifer seedlings has been well-demonstrated by several authors $(5,6,7,8,9,10,38,41,43,49)$. In such a model system, host seedlings are grown under controlled and sterile conditions that minimize potential effects by other stressors. Potential genetic differences between individuals are also minimally expressed at this juvenile stage of development (49).

The goals of this study were to (i) develop a technique with which to study the host-pathogen interaction between Douglas-fir and $P$. sulphurascens under controlled conditions in a laboratory, (ii) document the mode of infection of the fungus in roots of young Douglas-fir, and (iii) examine the expression and localization of four specific PR proteins known or suspected to occur in mature Douglas-fir roots infected by the fungus.

\section{MATERIALS AND METHODS}

Fungal strain. Inoculum of $P$. sulphurascens was prepared by placing $P$. sulphurascens isolate PFC-581 onto petri plates containing $1.5 \%$ malt extract agar. The isolate was originally collected from the stem of an infected, mature Douglas-fir tree near Cowichan Lake on Vancouver Island, British Columbia, Canada. Cultured mycelia were maintained in cryovials containing doubledistilled water $\left(\mathrm{ddH}_{2} \mathrm{O}\right)$, at $3^{\circ} \mathrm{C}$, in the form of agar plugs. These mycelia were further used to inoculate plates containing $1 \%$ (wt/vol) water agar; these were incubated for about 20 days and used as a source for $P$. sulphurascens in subsequent inoculation experiments.

Plant material and inoculation technique. Two families of coastal Douglas-fir (cross 1:38 × 299 and cross 2:80 × 69) were selected to provide germinated seeds because preliminary experiments (data not shown) demonstrated that they had similarly fast germination rates and high percentages of germination success, as well as little to no contamination after surface sterilization. Although we treated seeds from each family separately, our goal was not to compare them but to use them as a common source of juvenile Douglas-fir tissue. Seeds from the two families were first soaked in $\mathrm{ddH}_{2} \mathrm{O}$ for $24 \mathrm{~h}$ and stratified at $4^{\circ} \mathrm{C}$ for approximately 21 days. Seeds were then surface sterilized in $35 \% \mathrm{H}_{2} \mathrm{O}_{2}(\mathrm{vol} / \mathrm{vol})$ for 10 to $12 \mathrm{~min}$ with agitation, and rinsed at least four times with sterile $\mathrm{ddH}_{2} \mathrm{O}$. The sterilized seeds were sown in petri plates $(20$ to 25 seeds per plate) containing $1 \%$ (wt/vol) water agar and allowed to germinate at $24 \pm 1{ }^{\circ} \mathrm{C}$ in darkness. Germinated seedlings (10 to 14 days old) were used for the inoculations. Im- mediately prior to being inoculated, seedlings were aseptically transferred to bi-partitioned petri plates: one half of each plate contained $1 \%(\mathrm{wt} / \mathrm{vol})$ water agar and the other half was kept empty. The partition in each plate had a small section in the middle removed so that seedlings (about 10 to 20 per plate) could be placed flat, with their roots resting on the water agar portion and their foliage resting in the empty portion. A block of $P$. sulphurascens inoculum $(3.5 \times 2.0$ to $4.0 \mathrm{~cm})$ was placed over the root systems of all seedlings in each plate. The remaining seedlings were designated as controls; their root systems received agar blocks without $P$. sulphurascens mycelia. Petri plates were sealed with paraffin film and the halves containing treated roots were covered by aluminum foil and incubated for a $16 \mathrm{~h}$ photoperiod (50 to $60 \mu \mathrm{mol} \mathrm{m} \mathrm{m}^{-2} \mathrm{~s}^{-1}$ ) at $20^{\circ} \mathrm{C}$ for periods that varied in subsequent experiments.

Tissue preparation for light microscopy to document fungal infection. Two- to three-centimeter pieces of root (excluding the root tip) were excised from inoculated seedlings at 3, 5, 7, and 14 days postinoculation (dpi) and examined with light microscopy using a proprietary embedding technique provided in the manufacturer's guide (Technovit 7100; Heraeus Kulzer GmbH \& Co. KG, Wehrheim, Germany). Root pieces were fixed in FAA solution (10\% formalin, $10 \%$ acetic acid, and $90 \%$ ethyl alcohol) for 24 to $48 \mathrm{~h}$ prior to transfer to $70 \%$ ethanol. Following a dehydration procedure, samples were first preinfiltrated with a solution containing an equal volume of $100 \%$ ethanol and Technovit 7100 for $2 \mathrm{~h}$ at room temperature and then infiltrated with infiltration solution A (100 ml of Technovit $7100+1 \mathrm{~g}$ of Hardener I) for up to $24 \mathrm{~h}$. After infiltration, samples were placed into an embedding pan containing about $10 \mathrm{ml}$ of embedding solution $\mathrm{B}$ (15 parts infiltration solution $A+1$ part Hardner II) for $1 \mathrm{~h}$ at room temperature, and then $1 \mathrm{~h}$ at $37^{\circ} \mathrm{C}$ to allow polymerization of the embedding solution. Several radial sections ( $2 \mu \mathrm{m}$ thick) were cut from the lengths of prepared root pieces with glass knives on a JKB pyramitome (model 11800, JKB, Sweden) and mounted on glass slides. Mounted sections were stained for $30 \mathrm{~s}$ with $0.05 \%$ aqueous toluidine blue, rinsed with $\mathrm{ddH}_{2} \mathrm{O}$ for $1 \mathrm{~min}$, air dried, and cover slipped with Fisher Permount (Fisher Scientific, Ottawa, Canada). Stained sections were examined under a light microscope (Nikon Digital Camera, COOLPIX4500, Nikon Corporation, Tokyo, Japan).

Immunofluorescence to detect localization of PR proteins. Two- to three-centimeter pieces of root (excluding the root tip) were collected from inoculated seedlings at 3, 7, and 12 dpi for fluorescence microscopy to detect the location of four PR proteins known or suspected to occur in Douglas-fir roots infected by $P$. sulphurascens $(23,25,62,76)$. Root pieces were not collected at 5 dpi (because of their similarity to 7 dpi samples) and 14 dpi (because of their advanced state of decay) (data not shown). Because of their limited number, control uninfected samples were collected after 12 days only. Root pieces were prepared by following the same protocol used in the light microscopy experiment, except that fixation was accomplished with $2.5 \%$ paraformaldehyde in phosphate-buffered saline (PBS; $0.26 \mathrm{~g}$ of $\mathrm{KH}_{2} \mathrm{PO}_{4}$, $2.17 \mathrm{~g}$ of $\mathrm{Na}_{2} \mathrm{HPO}_{4}-7 \mathrm{H}_{2} \mathrm{O}$, and $8.71 \mathrm{~g}$ of $\mathrm{NaCl}$ in 1 liter of $\mathrm{dH}_{2} \mathrm{O}$, $\mathrm{pH}$ 7.4). Following fixation of root pieces, root cross sections were cut and mounted on glass slides and soaked in PBS for 5 min. To block the nonspecific binding of proteins, slides were incubated in PBS containing 1\% bovine serum albumin (BSA) for 20 to $30 \mathrm{~min}$. Slides were washed with PBS three times, for $5 \mathrm{~min}$ each time, and then incubated with four specific polyclonal antibodies developed against four proteins: a Douglas-fir thaumatinlike protein (PmTLP), an endochitinase protein (ECP), a DFPR10 (PsemI), and a 10.6-kDa antimicrobial peptide (PmAMP1) previously reported in Pinus monticola (23), but of unknown occurrence in Douglas-fir. Because of the intrinsic role that antimicrobial peptides play in plant host defenses against pathogenic infection (26), we suspected that we might find evidence of 
PmAMP1 in Douglas-fir seedlings challenged by P. sulphurascens. Incubation of root sections with the primary antibodies occurred overnight in a dilution of 1:100 with PBS containing $0.1 \%$ BSA. Slides were washed with PBS three times (5 min per wash) and incubated with fluorescein isothiocyanate-conjugated goat anti-rabbit IgG (immunoglobulin G whole molecule; SigmaAldrich, Oakville, Canada) in PBS containing 0.1\% BSA with a dilution of 1:50 ( $\mathrm{vol} / \mathrm{vol})$ for $30 \mathrm{~min}$. Slides were washed three times ( 5 min per wash) with PBS and air-dried prior to mounting with a coverslip. The sections were viewed using an epifluorescence microscope equipped with a digital camera (Zeiss Universal, Carl Zeiss Inc., Germany). At least three different root pieces (replications) were collected at each of the three sample times for all four of the primary antibodies used. A minimum of 10 root cross sections per replicate were viewed. Fluorescence in each immunolabeled root section was assessed visually for occurrence and rated as non- to minimally evident, moderately evident, or strongly evident. Localization of fluorescence was also determined visually.

Protein extraction. To characterize the four proteins in Douglasfir seedlings, approximately $200 \mathrm{mg}$ (fresh weight) of whole root tissue was collected from a total of 15 to 20 P. sulphurascensinfected seedlings at 3, 7, and 12 dpi. A control sample was collected at 12 days only. Samples were immediately frozen in liquid nitrogen and stored at $-80^{\circ} \mathrm{C}$. Extraction of all combined proteins and determination of protein concentrations in all samples were performed according to the protocol of Ekramoddoullah and Davidson (20), with minor modifications. Briefly, frozen root samples (ca. $100 \mathrm{mg}$ ) were ground to powder in liquid nitrogen with a homogenizer and extracted with $1 \mathrm{ml}$ of extraction buffer (4\% sodium dodecyl sulphate [SDS], 5\% 2-mercaptoethanol, and $4 \%$ sucrose). Protein was precipitated from the extraction buffer with acetone, and collected by centrifugation for $30 \mathrm{~min}$ at 14,000 rpm at room temperature, using a Sigma 1-15 microcentrifuge (Montreal Biotech Inc., Dorval, Canada). The protein pellets were each resuspended in $100 \mu \mathrm{l}$ of extraction buffer, supplemented with a $1 \%$ aqueous solution of Nonidet P-40 (NP-40; Sigma), and stored at $-20^{\circ} \mathrm{C}$ until used. To determine the presence of the four proteins in the foliage of the same 15 to 20 P. sulphurascensinfected seedlings whose roots were sampled, needle proteins were also extracted and their concentrations were determined with this protocol.

Western immunoblot analysis and protein quantification. Total combined/unseparated protein extracts from roots and needles of control and P. sulphurascens-infected seedlings were separated using 12\% SDS-polyacrylamide gel electrophoresis. Separated proteins were electrophoretically transferred to polyvinylidene fluoride membrane (Millipore Corp., Bedford, MA) and probed with polyclonal antibodies to PmTLP, ECP, DF-PR10, and PmAMP1 proteins following a standard protocol (22). To calibrate the gels, positive controls known to contain these PR proteins $(23,25,62,76)$ were applied to all gels. Developed membranes were scanned using a GS-800 computer-interfaced imaging densitometer (Bio-Rad Laboratories, Mississauga, Canada). Quantity One software (version 4.4, Bio-Rad Laboratories) was used for processing dot and western blots according to the instruction manual. The optical density (OD) of all the pixels within the band boundary was measured based on internal calibration standards specific to the scanner. The values were reported in optical density multiplied by bandwidth in millimeters $(\mathrm{OD} \times$ $\mathrm{mm}$ ). To confirm the reproducibility of results, western blot experiments were repeated.

Statistical analysis. Protein quantification data for control root samples and $P$. sulphurascens-infected root samples were analyzed using one-way analysis of variance (ANOVA) for inde-
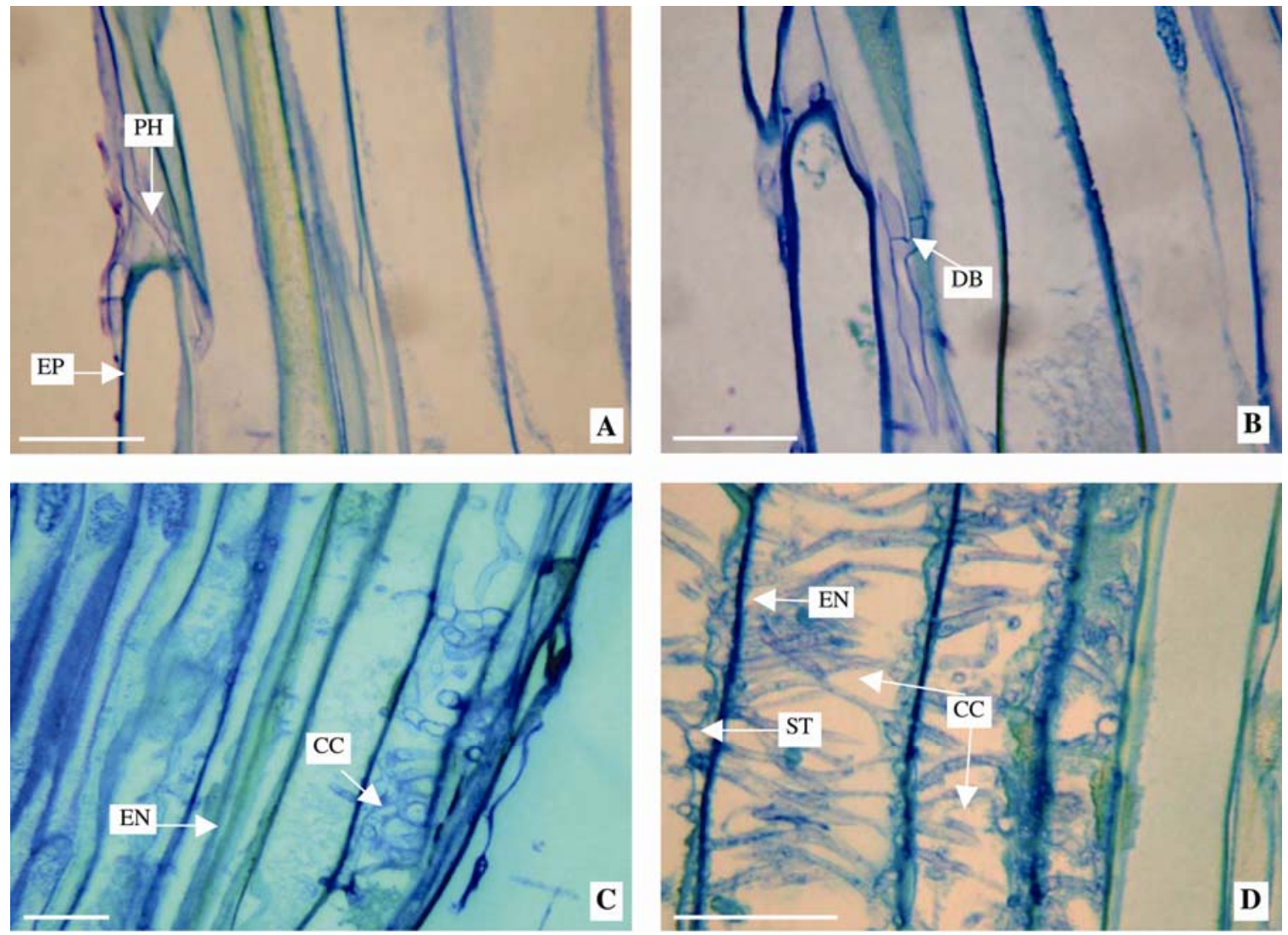

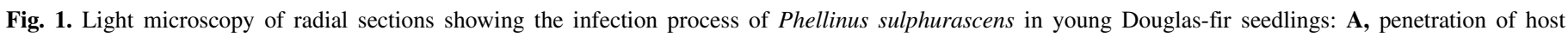

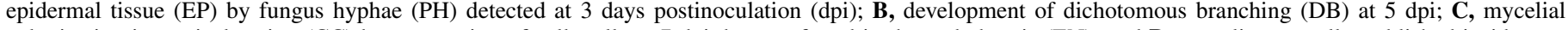

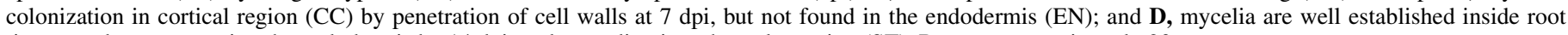
tissues and are penetrating the endodermis by $14 \mathrm{dpi}$, and extending into the stelar region (ST). Bars are approximately $20 \mu \mathrm{m}$. 
pendent samples, followed by Tukey's multiple range comparison tests to determine significance at $P<0.05$. ANOVA was performed using the VassarStats website for statistical computation.

\section{RESULTS}

Mode of penetration and internal colonization. Light microscopy of prepared slides of $P$. sulphurascens-infected roots stained with toluidine blue showed evidence of $P$. sulphurascens hyphae just inside root epidermal cells as early as 3 dpi (Fig. 1A). No necrotic browning of tissues was visible at this time. Following penetration of the epidermis, hyphae progressed rapidly inside the host tissues. Penetration hyphae were both intercellular and intracellular. Dichotomous branching of hyphae was observed at 5 dpi (Fig. 1B). Necrosis, evidenced by browning of tissues, was also visible at $5 \mathrm{dpi}$. There was extensive mycelial colonization and hyphal penetration in the root cortex at 7 dpi. Hyphae were more prevalent and concentrated in internal root tissues wherever there was evidence of mycelia on the root surface (Fig. 1C). The hyphae had penetrated the endodermis to the stelar region by 14 dpi (Fig. 1D), although colonization of this region at 14 dpi was very low in comparison to cortical colonization. By $14 \mathrm{dpi}$, prominent necrotic browning was observed along the entire length of infected roots (average length of root at this stage was 6 to $8 \mathrm{~cm}$ ) due to broad fungal colonization; this was accompanied by extensive cortical cell decay. Infected roots were completely decayed and disintegrated at $20 \mathrm{dpi}$. Uninfected control roots did not show any necrotic browning by $14 \mathrm{dpi}$; however, some tissue discoloration, likely due to dehydration, occurred in some portions where the roots did not adhere to the surface of the agar medium.

Immunolocalization of $\mathbf{P R}$ proteins. Immunofluorescence was used to investigate both the occurrence and localization of four PR proteins in uninfected and $P$. sulphurascens-infected roots. The immunolabeling of PmTLP, ECP, DF-PR10, and PmAMP1 proteins is shown in Figure 2. For all four proteins, evidence of fluorescence was strongest in cortical tissues; however, labeling varied by antibody and incubation period. Almost no labeling was evident in any of the uninfected control root sections (Fig. 2) or those sampled at 3 dpi (data not shown).

Labeling of all four PR proteins was more evident and more easily detectable in root sections at $7 \mathrm{dpi}$, with PmTLP and ECP labeling stronger than DF-PR10 or PmAMP1. At 7 dpi, labeling was most prominent throughout cortical tissues with little fluorescence occurring in the steler region. Immunofluorescence was even more evident in seedling root sections at $12 \mathrm{dpi}$. For PmTLP and ECP, fluorescence labeling was observed in vascular and cortical tissues, but was strongest in cortical tissues (Fig. 2).

Photomicrographs of root sections (12 dpi) taken at a higher magnification $(\times 100)$ show that all four PR proteins were localized, albeit in an irregular or spotty pattern, around the cell walls and intercellular spaces of infected roots. The PmTLP was the only one found to be localized in plastid-like organelles within cells. Among the four proteins, DF-PR10 had the weakest fluorescence (Fig. 3).

Western immunoblot analysis. Western immunoblot data show upregulation of all four PR proteins in roots inoculated with P. sulphurascens (Figs. 4 and 5). PmTLP accumulation was markedly increased in roots of $P$. sulphurascens-infected seedlings, whereas there was little to no PmTLP accumulation in needles of either infected or uninfected seedlings (Fig. 4). The highest concentration of PmTLP (OD 4.36) was found in inoculated roots at $12 \mathrm{dpi}$; this value differed significantly from concentrations in uninfected controls and roots sampled at 3 and 7 dpi $(P<0.01)$. However, PmTLP concentrations at 3 dpi (OD $1.00)$ and 7 dpi (OD 1.93) were not significantly different from concentrations in uninfected roots (Fig. 5).
There was a clear increase in the amount of ECP in roots of $P$. sulphurascens-infected seedlings, with the highest accumulation occurring in inoculated roots at $7 \mathrm{dpi}$ (OD 4.41). This value differed significantly from ECP concentrations in uninfected control root samples and 3-dpi (OD 1.83; $P<0.01)$ and 12-dpi root samples (OD 2.97; $P<0.01$ ) (Fig. 5). Similar to PmTLP accumulation, there was very little or no ECP accumulation detected in needles of infected or uninfected seedlings (Fig. 4).

Accumulation of the DF-PR10 protein in infected roots was not as high as for the other three PR proteins investigated. Regardless, the amount of DF-PR10 in infected roots was significantly different from the amount in control roots. The highest concentration of DF-PR10 occurred in inoculated roots at $7 \mathrm{dpi}$ (OD 0.76) and the second highest at $12 \mathrm{dpi}(\mathrm{OD} 0.55)$. Although these two values did not differ significantly, they were significantly different from the concentrations in uninfected and 3-dpi root samples $(P<$ 0.01) (Fig. 5). There was no detectable DF-PR10 accumulation in needles of infected or uninfected seedlings (Fig. 4).

The anti-PmAMP1 antibody bound to a protein band equivalent to the expected size of $10.6 \mathrm{kDa}$ in root and needle tissues from both infected and uninfected seedlings. There was a marked increase in PmAMP1 accumulation (OD 4.08) in infected roots at $12 \mathrm{dpi}$; this value differed significantly from concentrations in uninfected $(P<0.01)$ and 3 -dpi root samples $(P<0.05)$. The amount of $P m$ AMP1 (OD 3.37) at 7 dpi did not significantly differ from that in 12-dpi root samples (Fig. 4). PmAMP1 concentration in uninfected root samples (OD 0.71) did not vary significantly from that in roots at $3 \mathrm{dpi}$ (OD 0.92) (Fig. 5). Of the four proteins investigated in this study, PmAMP1 was the only one that was clearly detectable in needle tissues of infected seedlings.

\section{DISCUSSION}

In this study, we demonstrate use of an in vitro system that can be used to investigate several aspects of the Douglas-fir- $P$. sulphurascens interaction. Adapted in part from a model system described in Asiegbu et al. (5), our technique involves inoculation of young Douglas-fir seedlings with slabs of $P$. sulphurascens mycelia in petri dishes under uniform, sterile laboratory conditions. Such conditions, which minimize external biotic and abiotic effects, enable easier and more accurate study of many aspects of host-pathogen interactions. A drawback to using such a seedling model system is that results cannot be directly extrapolated to older trees. Any conclusions made about host-pathogen interactions based on seedling model systems must be validated using mature trees and natural infection conditions.

Mode of penetration and internal colonization. Our light microscopic observations indicate that $P$. sulphurascens mycelia can directly penetrate root epidermis cell walls within 3 days of inoculation. The fungus dichotomously branched and formed infective structures inside root tissue by $5 \mathrm{dpi}$ in order to colonize inside host tissues. Within $14 \mathrm{dpi}, P$. sulphurascens was well established inside cortical tissues and had penetrated the root endodermis to the vascular region. By $20 \mathrm{dpi}$, most of the inoculated roots were completely decayed and consumed by the fungus. These results are similar to those for other pathogenic fungi affecting conifer roots. Heneen et al. (38) reported that $H$. annosum can infect and degrade nonsuberized Norway spruce (Picea abies (L.) Karst.) seedlings as early as $3 \mathrm{dpi}$. It was also observed in this study that mycelia can extensively colonize cortical tissues by 5 to $7 \mathrm{dpi}$, whereas mycelia were detected around the endodermis after 12 to 15 dpi. Asiegbu (5) observed that the pregerminated conidiospores of $H$. annosum can form infective structures on root surfaces of Norway spruce seedlings within $24 \mathrm{~h}$ of inoculation. These authors also demonstrated that $H$. annosum can reach and partially destroy the vascular region by 12 dpi. Similarly, Li and Asiegbu (49) observed $H$. annosum causing an extensive dis- 
integration of cortical cells of Scots pine (Pinus sylvestris L.) seedling roots by 6 to $9 \mathrm{dpi}$, and of meristematic tissues by 10 to 15 dpi. Kozlowski and Métraux (43) demonstrated that Pythium can produce disease symptoms on roots in Picea abies seedlings by 2 to 3 dpi.

Immunolocalization of PR proteins. Our immunofluorescence experiment clearly showed the upregulation of several PR proteins over time in Douglas-fir roots after infection by $P$. sulphurascens. Accumulation of host-encoded soluble proteins is well established as a consequence of the expression of an array of PR genes during pathogen attack $(48,64)$. These proteins not only accumulate locally in infected tissues, but also are induced systemically to establish systemic-acquired resistance in hosts (69). Such systemic resistance provides defense against pathogenic constraints and general adaptation to stressful environments (18). Overall, evidence of fluorescence in $P$. sulphurascens-infected roots was found to be strongest in the root cortex, which is where the majority of fungal colonization occurred. In addition, in the four sample times used, fluorescence was most evident at $12 \mathrm{dpi}$ when $P$. sulphurascens was well established inside host tissues. These results suggest that the accumulation of the four PR proteins investigated is related to $P$. sulphurascens infection and that they each play a potential defensive role against the fungus. These results agree with our previous findings for PmTLP (76), ECP (62), and the DF-PR10 protein (25).

Immunolabeling of PmTLP and ECP was stronger than labeling of DF-PR10 and PmAMP1 in infected roots. High concentrations of PmTLP (76) and ECP (77) have previously been reported in both roots and needles of mature Douglas-fir infected by $P$. sulphurascens. All four PR proteins investigated were localized around the cell walls and intercellular spaces. The intercellular extraprotoplastic matrix of plant cells, including the cell walls, can be defined as the plant apoplast (15). Given that the apoplast is the first site of contact and interaction between a pathogen and its host, it clearly plays a crucial role in the initiation and coordination of many defense responses (11), including accumula-
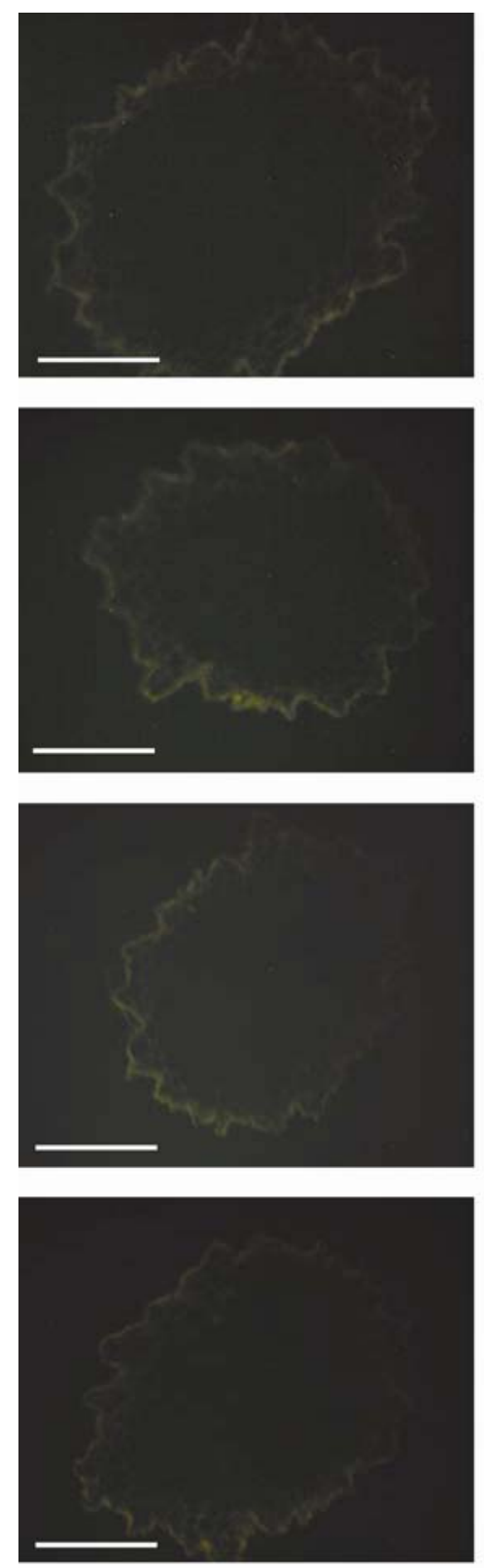

Control
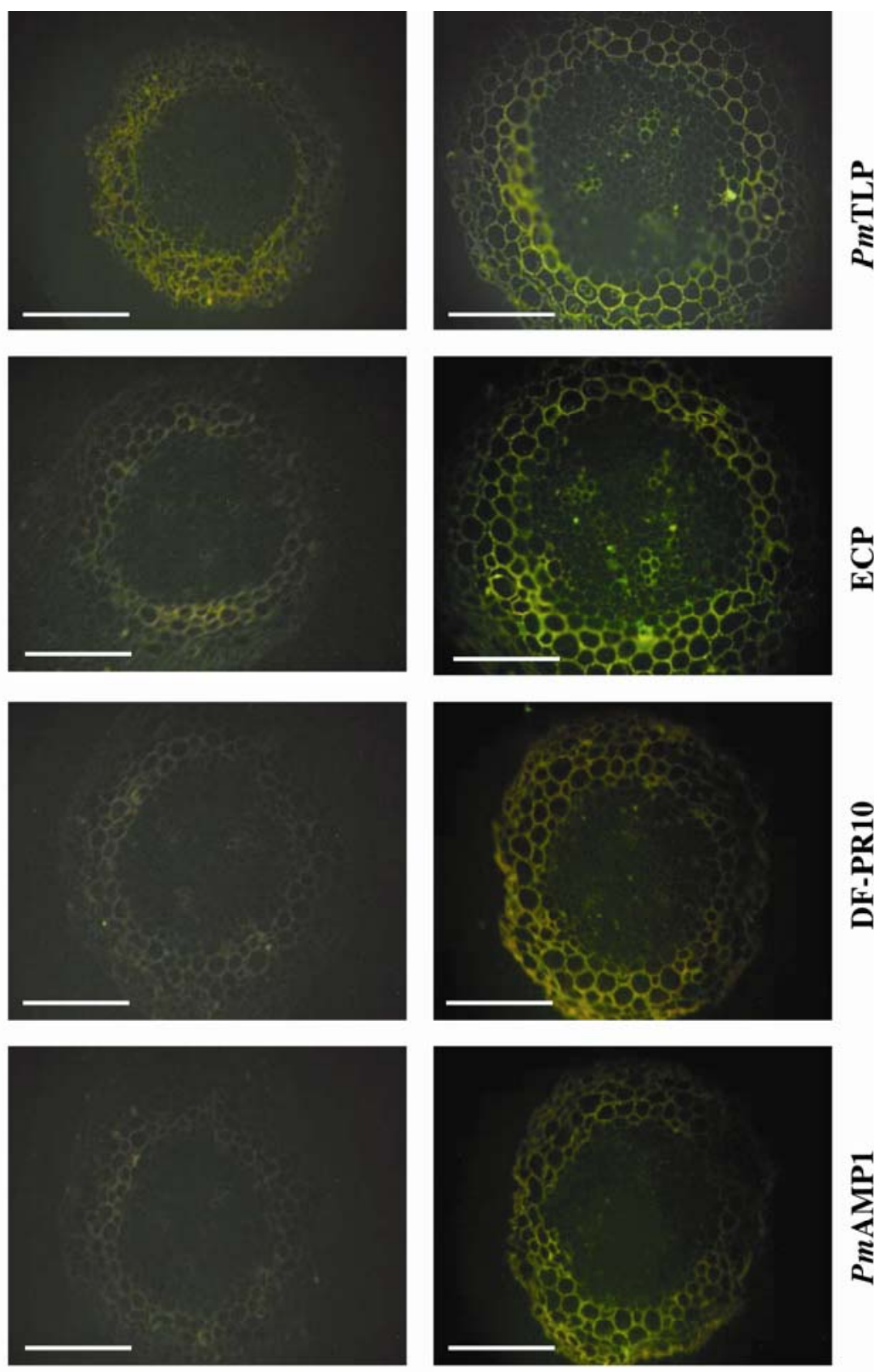

7 dpi

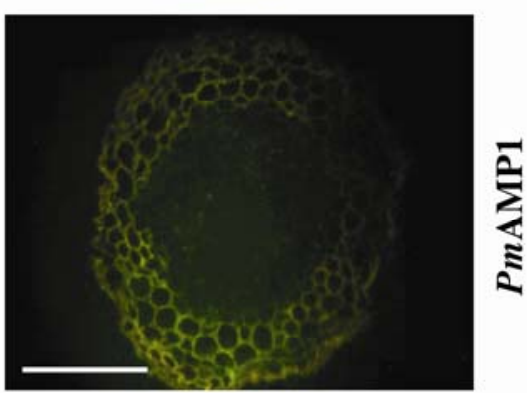

12 dpi

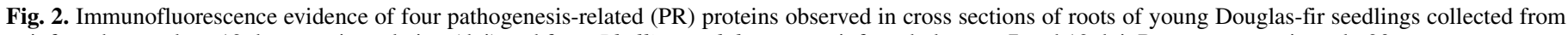
uninfected controls at 12 days postinoculation (dpi) and from Phellinus sulphurascens-infected plants at 7 and 12 dpi. Bars are approximately 20 m. 
tion of PR proteins (69). Of the four PR proteins investigated in our study, the PmTLP was the only one to also occur in plastidlike organelles within cortical cells. The reason for this apparently unique localization is not clear. Other PR and stress-related proteins have been demonstrated to occur in plastids. These include PCA60, a dehydrin from peach (72), and a TLP from barley floral organs (50).

Western immunoblot analysis. Western blot results demonstrated that the accumulation of all four proteins began within $3 \mathrm{dpi}$, even though there was no visible evidence of necrotic browning at that time. This rate of host response to pathogen infection, measured in days rather than minutes or hours, is different from the fast, single gene-mediated response often seen in angiosperm crop pathosystems. In these systems, visible hypersensitive response-related symptoms often occur in angiosperm hosts within hours of infection (37). Reasons for why some gymnosperm pathosystems may respond in a slower manner to a pathogen attack include the possibility that hosts lack sufficient information about the nature of a pathogen attack during the initial stages of infection (27) or that the pathogen has the ability to avoid immediate recognition during the initial stages of interaction (2). Our western blot results also demonstrated that the accumulation of all four proteins was five to six times greater in $P$. sulphurascens-infected Douglas-fir roots than in uninfected control seedlings. The largest accumulation of PmTLP and PmAMP1 was found at $12 \mathrm{dpi}$, whereas the highest concentrations of ECP and DF-PR10 were found at 7 dpi. Robinson et al. (62) and Zamani et al. (76) reported a 10-fold and a 6-fold higher concentration of ECP and PmTLP, respectively, in infected versus noninfected root bark tissues of Douglas-fir trees inoculated with $P$. sulphurascens. These collective observations confirm that both ECP and PmTLP are highly expressed in both mature and juvenile Douglas-fir roots in response to $P$. sulphurascens infection. Upregulation of all four PR proteins in P. sulphurascens-infected Douglas-fir also supports a defense-related role for them in the host-pathogen interaction.

Members of the PR5 family of proteins have demonstrated antifungal activity in vitro. In agronomic crops, overexpression of TLPs in rice (13) and osmotin-like proteins in potato (78) have resulted in enhanced resistance to pathogens. It has been suggested that these proteins contribute to damage of pathogen cell walls by increasing cell-membrane permeability (1).

Plant chitinases hydrolyze chitin (59), a major component of fungus cell walls. Plant chitinases appear to inhibit in vitro fungal germination and mycelial elongation by tipping the balance between hyphal-wall synthesis and lysis in favor of lytic digestion (63). Recently, a class IV chitinase was found to be associated with slow-canker growth resistance to Cronartium ribicola J.C. Fisch. in western white pine (53).

It is not clear why there was a reduction of ECP expression at 12 dpi. However, because we do know that chitinases have roles in both plant development and defense $(14,17,66)$, this change in expression could be related to interactions between these activities. In an immunolocalization study with barley flower, Liljeroth et al. (50) reported that the strongest labeling of chitinase occurred at an early developmental stage and decreased during later developmental stages. Hietala et al. (39) reported that class I chitinase transcript levels declined in Norway spruce in response
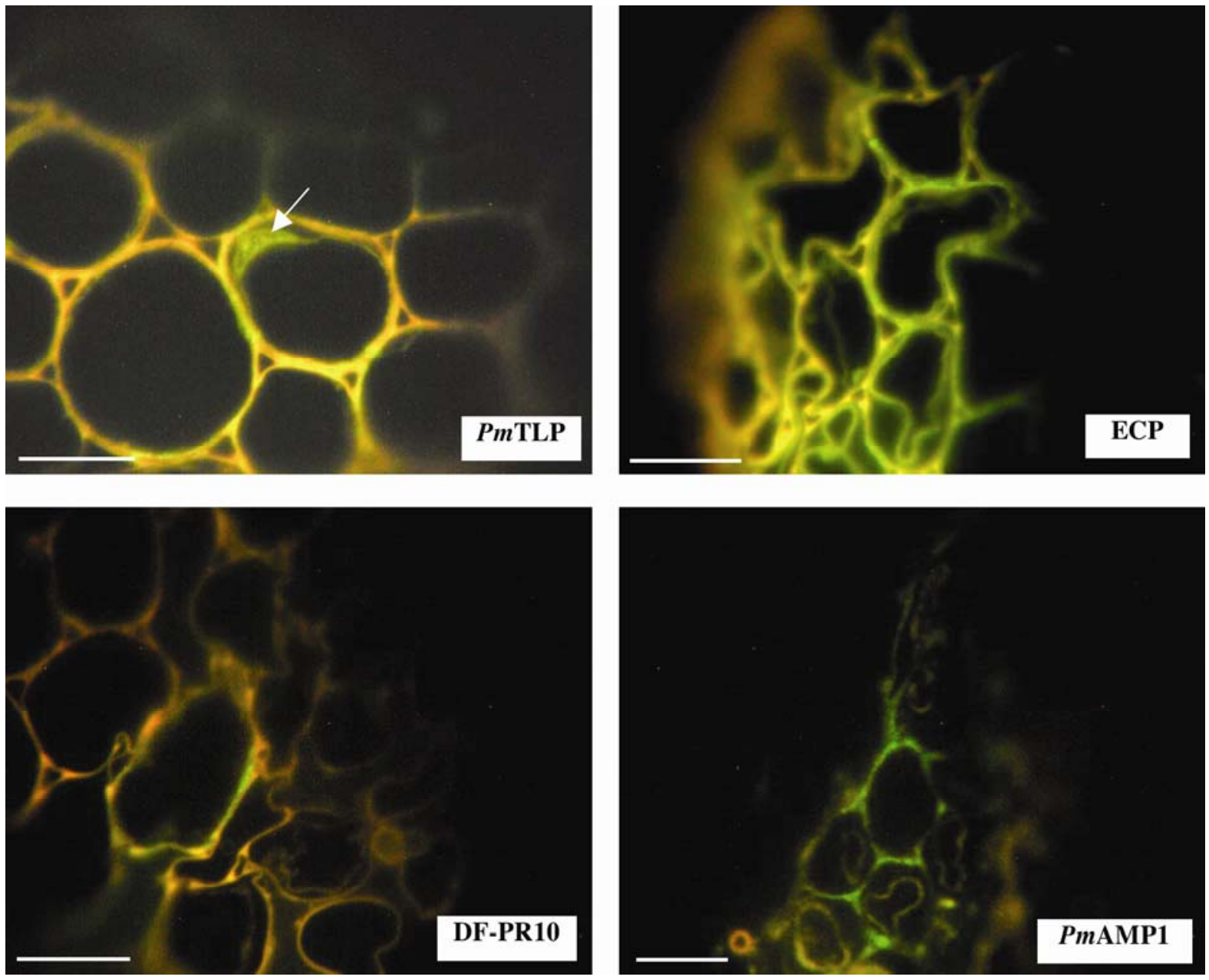

Fig. 3. Immunofluorescence of four pathogenesis-related (PR) proteins observed in cross sections of roots of young Douglas-fir seedlings infected by Phellinus sulphurascens. Images are at a higher magnification $(\times 100)$ than in Figure 2. Arrow shows plastid-like organelle labeled with PmTLP. Bars are approximately $5 \mu$ m. 
to bark colonization by $H$. annosum, whereas classes II and IV levels increased after the same treatment. Furthermore, Fujita et al. (28) reported that the powdery mildew pathogen, Blumeria graminis, can suppress chitinase gene expression in infected barley coleoptiles. However, whether endogenous developmental activities affect the regulation of endochitinase gene or whether this is downregulated through activation of fungus-derived suppressors remains to be determined.

The PR10 proteins belong to a relatively diverse family. Many members are proposed to have ribonuclease activity in plants, especially in response to pathogens and abiotic stressors, whereas
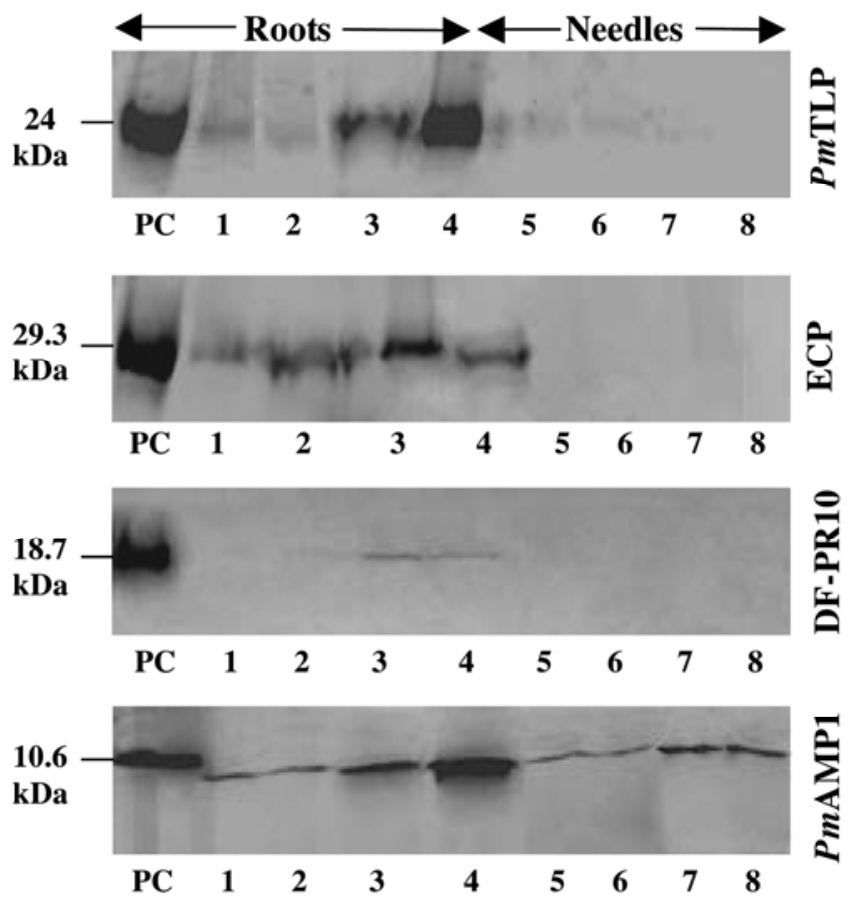

Fig. 4. Western immunoblots show the concentrations of four pathogenesisrelated (PR) proteins in root (lanes 1 to 4 ) and needle (lanes 5 to 8 ) samples of young Douglas-fir seedlings collected from uninfected controls at 12 days postinoculation (dpi) and from Phellinus sulphurascens-infected plants at 2, 7, and 12 dpi. PC-positive controls (obtained from Douglas-fir needles for ECP, PmTLP, and DF-PR10, and from western white pine needles for PmAMP1). Lanes 1 and 5, uninfected controls; lanes 2 and 6, 2 dpi; lanes 3 and 7, 7 dpi; and lanes 4 and 8, 12 dpi. others appear to be more involved in developmental processes and enzymatic activities in secondary metabolism (52). In this study, the DF-PR10 protein was barely detectable in P. sulphurascensinfected Douglas-fir roots, with expression first appearing at $7 \mathrm{dpi}$ and dropping slightly at $12 \mathrm{dpi}$. This was similar to the reduction over time seen for ECP and possibly occurred for the same reasons. A study by Ekramoddoullah et al. (25) also showed evidence for upregulation of the DF-PR10 in P. sulphurascensinfected Douglas-fir roots. However, these authors also found that the expression of the DF-PR10 protein in noninfected Douglas-fir seedlings was very low in comparison with the expression of a very similar PR10 protein (PinmIII) in western white pine (Pinus monticola Douglas ex D. Don) seedlings. Western white pine is considered tolerant to infection by $P$. sulphurascens (67), although the reasons for this tolerance are not known. High expression levels of the PR10 PinmIII protein have been reported in western white pine in response to infection by the blister rust fungus, $C$. ribicola $(19,24,74)$. It is possible that this PinmIII protein in western white pine also plays a role in its resistance to $P$. sulphurascens. This could be investigated by assessing its accumulation in western white pine seedlings individually challenged by both pathogens. Interestingly, recent work in our laboratory has shown that a purified recombinant PinmIII protein has inhibitory activity against $P$. sulphurascens in vitro.

In this study, we detected a $10.6-\mathrm{kDa}$ antimicrobial peptide in Douglas-fir by using an antibody previously developed against antimicrobial peptide PmAMP1 in western white pine (23). We found increased concentrations of this $10.6-\mathrm{kDa}$ peptide in Douglas-fir roots relative to control seedlings after inoculation with $P$. sulphurascens, with the highest expression occurring at 12 dpi. These results demonstrate that this PR protein is constitutively expressed in Douglas-fir but upregulated after pathogen attack. Expression of PmAMP1 is known to be associated with slow-canker-growth resistance to $C$. ribicola in western white pine (23). The fact that this antimicrobial peptide, or one very similar to it, is upregulated in Douglas-fir after P. sulphurascens infection, further supports its defense-related role in the Douglasfir-laminated root rot pathosystem. Ekramoddoullah et al. (23) reported a significant homology between PmAMP1 and two broadspectrum antifungal proteins: MiAMPI, isolated from Macadamia integrifolia (54), and Sp-AMP, isolated from Pinus sylvestris (4). In our laboratory, a purified recombinant PmAMP1 was shown to have inhibitory activity against both $C$. ribicola $(75)$ and, more recently, $P$. sulphurascens. Marcus et al. (54) demonstrated in vitro the inhibitory activity of MiAMPI against fungi, oomycetes,

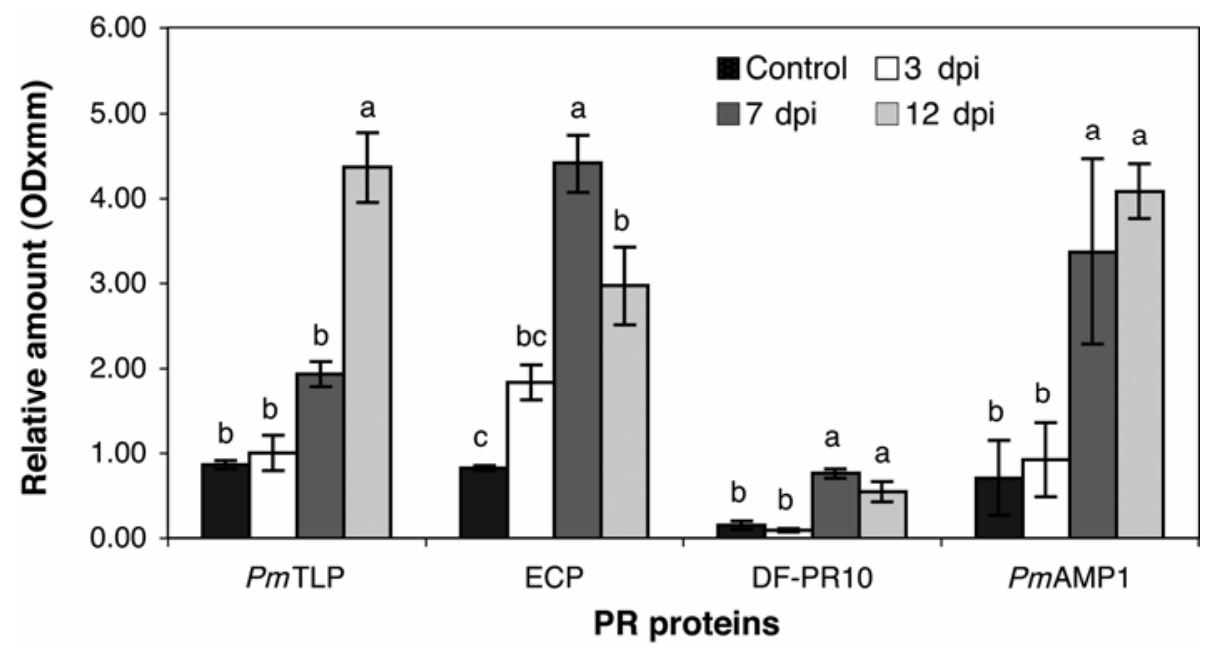

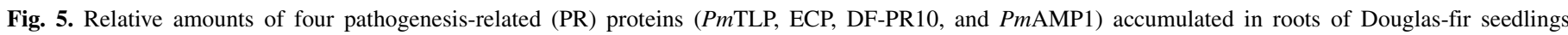

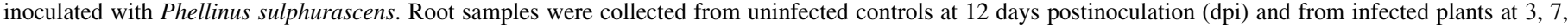

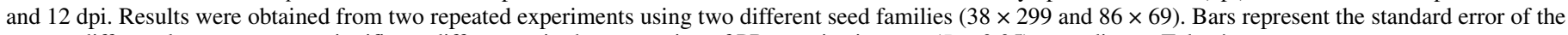
means; different letters represent significant differences in the expression of PR proteins in roots $(P<0.05)$ according to Tukey's test. 
and bacterial phytopathogens, as well as against human mycopathogens. Other authors have also observed that overexpression of this class of antimicrobial peptides in canola plants was effective in conferring resistance against Leptosphaeria maculans, the fungal pathogen causing stem canker (42).

We were somewhat surprised by the very low expression of both PmTLP and ECP in needles of our inoculated Douglas-fir seedlings, especially as our previous work showed induction of both of these proteins in root and needle tissues of infected Douglas-firs $(76,77)$. It is possible that this differential expression is related to the very young age and developmental stage of our experimental seedlings and to the controlled environmental conditions under which they were grown. Previously, we used naturally grown mature or juvenile plant materials; these would have had a much longer exposure time to the fungus and to other possible biotic and abiotic stressors, and thus would have been more likely to have marshaled PR proteins locally and systemically. Agerelated resistance has been investigated in a number of plant species, and a number of PR genes were found to be upregulated at different developmental stages. For example, Arabidopsis becomes more resistant to virulent Pseudomonas syringae as the plant matures (45). Tobacco accumulates some specific PR proteins and becomes naturally resistant to blue mould caused by Peronospora tabacina as it ages (73).

The apparent lack of expression of the DF-PR10 in needle tissues is not surprising given its overall low expression in all infected tissues. Ekramoddoullah et al. (25) detected DF-PR10 in Douglas-fir needle samples, but its levels were extremely low in summer and increased over winter. Seasonal variation in expression of foliage proteins has also been reported in western white pine (21).

Finally, it is interesting to find that PmAMP1 expression, a systemic response, was noticeably greater in needles of $P$. sulphurascens-infected seedlings than were expression levels of the other three PR proteins looked at. We are unsure of why this would have been the case, especially as most AMPs studied to date appear to exert their antimicrobial effects at the level of the target microorganism's plasma membrane (23).

In conclusion, the in vitro inoculation technique we developed enabled us to study several aspects of the host-pathogen interaction between Douglas-fir and $P$. sulphurascens. We will now use this technique to study components contributing to resistance in this important pathosystem by investigating gene occurrence and expression in families of Douglas-fir known to be differentially resistant to $P$. sulphurascens.

\section{ACKNOWLEDGMENTS}

This work was funded in part by Natural Resources Canada, Canadian Forest Service, Forest Biotechnology/Genomics Initiative funds to R. Sturrock. We thank K. Pellow, A. Zamani, and T. Holmes for their technical support and the British Columbia Ministry of Forests and Range for providing Douglas-fir seeds.

\section{LITERATURE CITED}

1. Abad, L. R., D'Urzo, M. P., Liu, K., Narashimhan, M. L., Reuveni, M., Zhu, J. K., Niu, X., Singh, N. K., Hasegawa, P. M., and Bressen, R. A. 1996. Antifungal activity of tobacco osmotin has specificity and involves plasma membrane permeabilization. Plant Sci. 118:11-23.

2. Adomas, A. 2007. Transcript profiling of the Heterobasidion-conifer pathosystem: host and pathogen responses to biotic stress. Doctoral thesis, Swedish University of Agricultural Sciences, Uppsala, Sweden.

3. Antikainen, M., Griffith, M., Zhang, J., Hon, W.-C., Yang, D. S. C., and Phhakaski-Maunsbach, K. 1996. Immunolocalization of antifreeze proteins in winter rye leaves, crowns, and roots by tissue printing. Plant Physiol. 110:845-857.

4. Asiegbu, F. O., Choi, W., Li, G., Nahalkova, J., and Dean, R. A. 2003. Isolation of a novel antimicrobial peptide gene $(S p-A M P)$ homologue from Pinus sylvestris (Scots pine) following infection with the root rot fungus Heterobasidion annosum. FEMS Microbiol. Lett. 228:27-31.

5. Asiegbu, F. O., Daniel, G., and Johansson, M. 1993. Studies on the infection of Norway spruce roots by Heterobasidion annosum. Can. J. Bot. 71:1552-1561.

6. Asiegbu, F. O., Daniel, G., and Johansson, M. 1994. Defense related reactions of seedling roots of Norway spruce to infection by Heterobasidion annosum (Fr.) Bref. Physiol. Mol. Plant Pathol. 45:1-19.

7. Asiegbu, F. O., Daniel, G., and Johansson, M. 1996. Cellular interaction between the saprotroph Phlebiopsis gigantea and non-suberized roots of Picea abies. Mycol. Res. 100:409-417.

8. Asiegbu, F. O., Denekamp, M., Daniel, G., and Johansson, M. 1995. Immuno-cytochemical localization of pathogenesis-related proteins in roots of Norway spruce infected with Heterobasidion annosum. Eur. J. For. Pathol. 25:169-178.

9. Asiegbu, F. O., Kacprzak, M., Daniel, G., Johansson, M., Stenlid, J., and Manka, M. 1999. Biochemical interactions of conifer seedling roots with Fusarium spp. Can. J. Microbiol. 45:923-935.

10. Asiegbu, F. O., Nahalkova, J., and Li, G. 2005. Pathogen-inducible cDNAs from the interaction of the root rot fungus Heterobasidion annosum with Scots pine (Pinus sylvestris L.). Plant Sci. 168:365-372.

11. Bolwell, P. P., Page, A., Pislewska, M., and Wojtaszek, P. 2001. Pathogenic infection and the oxidative defenses in plant apoplast. Protoplasma 217:20-32.

12. Buckland, D. C., Molnar, A. C., and Wallis, W. G. 1954. Yellow laminated root rot of Douglas-fir. Can. J. Bot. 32:69-81.

13. Datta, K., Velazhahan, R., Oliva, N., Ona, I., Mew, T., Khush, G. S., Muthukrishnan, S., and Datta, S. K. 1999. Over-expression of the cloned rice thaumatin-like protein (PR-5) gene in transgenic rice plants enhances environmental friendly resistance to Rhizoctonia solani causing sheath blight disease. Theor. Appl. Genet. 98:1138-1145.

14. De Jong, A. J., Cordewener, J., Schiavo, F. L., Terzi, M., Vandekerckhove, J., Van Kammen, A., and De Vries, S. C. 1992. A carrot somatic embryo mutant is rescued by chitinase. Plant Cell 4:425-433.

15. Dietz, K.-J. 1997. Functions and responses of the leaf apoplast under stress. Prog. Bot. 58:221-254.

16. Dore, I., Legrand, M., Cornelissen, B. J., and Bol, J. F. 1991. Subcellular localization of acidic and basic PR proteins in tobacco mosaic virusinfected tobacco. Arch. Virol. 120:97-107.

17. Dyachok, J. V., Wiweger, M., Kenne, L., and von Arnold, S. 2002. Endogenous Nod-factor-like signal molecules promote early somatic embryo development in Norway spruce. Plant Physiol. 128:523-533.

18. Edreva, A. 2005. Pathogenesis-related proteins: Research progress in the last 15 years. Gen. Appl. Plant Physiol. 31:105-124.

19. Ekramoddoullah, A. K. M. 2004. Physiology and molecular biology of a family of pathogenesis-related PR-10 proteins in conifers. J. Crop Improv. 10:261-280.

20. Ekramoddoullah, A. K. M., and Davidson, J. J. 1995. A method for the determination of foliage protein extracted using sodium dodecyl sulphate and mercaptoethanol. Phytochem. Anal. 6:20-24.

21. Ekramoddoullah, A. K. M., and Taylor, D. W. 1996. Seasonal variation of western white pine (Pinus monticola D. Don) foliage proteins. Plant Cell Physiol. 37:189-199.

22. Ekramoddoullah, A. K. M., Davidson, J. J., and Taylor, D. W. 1998. A protein associated with frost hardiness of western white pine is upregulated by infection in the white pine blister rust pathosystem. Can. J. For. Res. 28:412-417.

23. Ekramoddoullah, A. K. M., Liu, J.-J., and Zamani, A. 2006. Cloning and characterization of a putative antifungal peptide gene (Pm-AMP1) in Pinus monticola. Phytopathology 96:164-170.

24. Ekramoddoullah, A. K. M., Taylor, D. W., and Hawkins, B. J. 1995. Characterization of a fall protein of sugar pine and detection of its homologue associated with frost hardiness of western white pine needles. Can. J. For. Res. 25:1137-1147.

25. Ekramoddoullah, A. K. M., Yu, X., Sturrock, R., Zamani, A., and Taylor, D. 2000. Detection and seasonal expression pattern of a pathogenesisrelated protein (PR-10) in Douglas-fir (Pseudotsuga menziesii) tissues. Physiol. Plant. 110:240-247.

26. Faye, T., Brede, D. A., Langsrud, T., Nes, I. F., and Holo, H. 2002. An antimicrobial peptide is produced by extracellular processing of a protein from Propionibacterium jensenii. J. Biotech. 184:3649-3656.

27. Franceschi, V. R., Krokene, P., Christiansen, E., and Krekling, T. 2005. Anatomical and chemical defenses of conifer bark against bark beetles and other pests. New Phytopathol. 167:353-376.

28. Fujita, K., Matsuda, Y., Wada, M., Hirai, Y., Mori, K., Moriura, N., Nonomura, T., Kakutani, K., and Toyoda, H. 2004. Powdery mildew pathogens can suppress the chitinase gene expression induced in detached inner epidermis of barley coleoptile. Plant Cell Rep. 23:504-511.

29. Garrett, S. D. 1956. Biology of Root-Infecting Fungi. Cambridge University Press, London, UK

30. Ghosh, M., and Ulaganathan, K. 2004. Immunolocalization of sorghum antifungal protein in embryogenic seed tissues. Curr. Sci. 86:24-26. 
31. Goheen, E. M., and Hansen, E. M. 1994. Tree vigor and susceptibility to infection by Phellinus weirii: Results of field inoculation. Pages 45-51 in: Proc. of the Eighth International Conference on Root and Butt Rots. M. Johansson and J. Stenlid, eds. International Union of Forestry Research Organization (IUFRO), Working party S2.06.01, Swedish University of Agricultural Sciences, Uppsala, Sweden.

32. Graham, L. S., and Sticklen, M. B. 1994. Plant chitinases. Can. J. Bot. 72:1057-1083

33. Grsic-Rausch, S., Kobelt, P., Siemens, J. M., Bischoff, M., and LudwigMueller, J. 2000. Expression and localization of nitrilase during symptom development of the clubroot disease in Arabidopsis. Plant Physiol. 122:369-378

34. Hansen, E. M. 1979. Survival of Phellinus weirii in Douglas-fir stumps after logging. Can. J. For. Res. 9:484-488.

35. Hansen, E. M., and Goheen, E. M. 2000. Phellinus weirii and other native root pathogens as determinants of forest structure and process in western North America. Annu. Rev. Phytopathol. 38:515-539.

36. Hashimoto, M., Kisseleva, L., Sawa, S., Furukawa, T., Komatsu, S., and Koshiba, T. 2004. A novel rice PR10 Protein, RSOsPR10, specifically induced in roots by biotic and abiotic stresses, possibly via the jasmonic acid signaling pathway. Plant Cell Physiol. 45:550-559.

37. Heath, M. C. 2000. Hypersensitive response-related death. Plant Mol. Biol. 44:321-334.

38. Heneen, W. K., Gustafsson, M., Karlsson, G., and Brismar, K. 1994. Interactions between Norway spruce (Picea abies) and Heterobasidion annosum. I. Infection of nonsuberized and young suberized roots. Can. J. Bot. 72:872-883

39. Hietala, A. M., Kvaalen, H., Schmidt, A., Johnk, N., Solheim, H., and Fossdal, C. G. 2004. Temporal and spatial profiles of chitinase expression by Norway spruce in response to bark colonization by Heterobasidion annosum. Appl. Environ. Microbiol. 70:3948-3953.

40. Hong, J. K., and Hwang, B. K. 2002. Temporal and subcellular localization of PR-1 proteins in tomato stem tissue infected by virulent and avirulent isolates of Phytophthora capsici. Protoplasma 219:131-139.

41. Karlsson, M., Olson, A., and Stenlid, J. 2003. Expressed sequences from the basidiomycetous tree pathogen Heterobasidion annosum during early infection of scots pine. Fungal Genet. Biol. 39:51-59.

42. Karzan, K., Rusu, A., Marcus, J. P., Goulter, K. C., and Manners, J. M. 2002. Enhanced quantitative resistance to Leptosphaeria maculans conferred by expression of a novel antimicrobial peptide in canola (Brassica napus). Mol. Breed. 10:63-70.

43. Kozlowski, G., and Métraux, J.-P. 1998. Infection of Norway spruce (Picea abies (L.) Karst.) seedlings with Pythium irregulare Buism. and Pythium ultimum Trow: Histological and biochemical responses. Eur. J. Plant Pathol. 104:225-234.

44. Kragh, K. M., Nielsen, J. E., Nielsen, K. K., Dreboldt, S., and Mikkelsen, J. D. 1995. Characterization and localization of new antifungal cysteinerich proteins from Beta vulgaris. Mol. Plant-Microbe Interact. 8:424-434.

45. Kus, J. V., Zaton, K., Sarkar, R., and Cameron, R. K. 2002. Age-related resistance in Arabidopsis is a developmentally regulated defense response to Pseudomonas syringae. Plant Cell 14:479-490.

46. Larsen, M. J., Lombard, F. F., and Clark, J. W. 1994. Phellinus sulphurascens and the closely related $P$. weirii in North America. Mycologia 86:121-130.

47. Laurenzi, M., Tipping, A. J., Marcus, S. E., Knox, P. J., Federico, R., Angelini, R., and McPherson, M. J. 2001. Analysis of the distribution of copper amine oxidase in cell walls of legume seedlings. Planta 214:37-45.

48. Legrand, M., Kauffmann, S., Geoffroy, P., and Fritig, B. 1987. Biological function of pathogenesis-related proteins: Four tobacco pathogenesisrelated proteins are chitinases. Proc. Natl. Acad. Sci. USA 84:6750-6754.

49. Li, G., and Asiegbu, F. O. 2004. Use of Scots pine seedlings roots as an experimental model to investigate gene expression during interaction with the conifer pathogen Heterobasidion annosum (P-type). J. Plant Res. 117:155-162.

50. Liljeroth, D., Marttila, S., and von Bothmer, R. 2005. Immunolocalization of defense-related proteins in the floral organs of barley (Hordeum vulgare L.). J. Phytopathol. 153:702-709.

51. Linthorst, H. J. M. 1991. Pathogenesis-related proteins of plants. Crit. Rev. Plant Sci. 10:123-150.

52. Liu, J.-J., and Ekramoddoullah, A. K. M. 2006. The family 10 of plant pathogenesis-related proteins: Their structure, regulation and function in response to biotic and abiotic stresses. Physiol. Mol. Plant Pathol. 68:3-13.

53. Liu, J. -J., Ekramoddoullah, A. K. M., and Zamani, A. 2005. A class IV chitinase is upregulated by fungal infection and abiotic stresses and associated with slow-canker-growth resistance to Cronartium ribicola in western white pine (Pinus monticola). Phytopathology 95:284-291.

54. Marcus, J. P., Goulter, K. C., Green, J. L., Harrison, S. J., and Manners, J. M. 1997. Purification, characterization and cDNA cloning of an antimicrobial peptide from Macadamia integrifolia. Eur. J. Biochem.
244:743-749.

55. Mullick, D. B., and Jensen, G. D. 1973. New concepts and terminology of coniferous periderms: Necrophylactic and exophylactic periderms. Can. J. Bot. 51:1459-1470.

56. Murillo, I., Cavallarin, L., and Segundo, B. S. 1999. Cytology of infection of maize seedlings by Fusarium moniliforme and immunolocalization of the pathogenesis-related PRms protein. Phytopathology 89:737-747.

57. Nahálková, J., Asiegbu, F. O., Daniel, G., Hrib, J. Vooková, B., Pribulová, B., and Gemeiner, P. 2001. Isolation and immunolocalization of a Pinus nigra lectin (PNL) during interaction with the necrotrophs-Heterobasidion annosum and Fusarium avenaceum. Physiol. Mol. Plant Pathol. 59:153-163.

58. Nelson, E. E., and Sturrock, R. N. 1993. Susceptibility of western conifers to laminated root rot (Phellinus weirii) in Oregon and British Columbia field tests. West. J. Appl. For. 8:67-70.

59. Punja, Z. K., and Zhang, Y.-Y. 1993. Plant chitinases and their roles in resistance to fungal disease. J. Nematol. 25:526-540.

60. Roberts, W. K., and Selitrennikoff, C. P. 1990. Zeamatin, an antifungal protein from maize with membrane-permeabilizing activity. J. Gen. Microbiol. 136:1771-1778.

61. Robinson, R. M., Morrison, D. J., and Jensen, G. D. 2004. Necrophylactic periderm formation in the roots of western larch and Douglas-fir trees infected with Armillaria ostoyae. II. The response to the pathogen. For. Pathol. 34:119-129.

62. Robinson, R. M., Sturrock, R. N., Davidson, J. J., Ekramoddoullah, A. K M., and Morrison, D. J. 2000. Detection of chitinase-like protein in the roots of Douglas-fir trees infected with Armillaria ostoyae and Phellinus weirii. Tree Physiol. 20:493-502.

63. Schlumbaum, A., Mauch, F., Vogeli, U., and Boller, T. 1986. Plant chitinases are potent inhibitors of fungal growth. Nature 324:365-567.

64. Stintzi, A., Heitz, T., Prasad, V., Widemann-Merdinoglu, S., Kauffmann, S., Geoffroy, P., Legrand, M., and Fritig, B. 1993. Plant 'pathogenesisrelated' proteins and their role in defense against pathogens. Biochemie 75:687-706.

65. Sturrock, R. N., Hall D., Jensen, G., and Holmes, T. 2002. Infection of roots of coastal Douglas-fir by Phellinus weirii. Pages 155-166 in: Proc. 48th Western International Forest Disease Work Conference. P. Angwin, ed. USDA FS, Northern California Shared Service Area, Redding, CA.

66. Takakura, Y., Ito, T., Saito, H., Inoue, T., Komari, T., and Kuwata, S. 2000. Flower-predominant expression of a gene encoding a novel class I chitinase in rice (Oryza sativa L.). Plant Mol. Biol. 42:883-897.

67. Thies, W. G., and Sturrock, R. N. 1995. Laminated root rot in western North America. U.S. Dep. Agric. For. Serv. PNW-GTR-349.

68. Thies, W. G., and Westlind, D. J. 2005. Stump removal and fertilization of five Phellinus weirii-infested stands in Washington and Oregon affect mortality and growth of planted Douglas-fir 25 years after treatment. For. Ecol. Manag. 219:242-258.

69. Van Loon, L. C., and Van Strien, E. A. 1999. The families of pathogenesis-related proteins, their activities, and comparative analysis of PR-1 type proteins. Physiol. Mol. Plant Pathol. 55:85-97.

70. Wallis, G. W., and Reynolds, G. 1962. Inoculation of Douglas-fir roots with Poria weirii. Can. J. Bot. 40:637-645.

71. Wallis, G. W., and Reynolds, G. 1965. The initiation and spread of Poria weirii root rot of Douglas-fir. Can. J. Bot. 43:1-9.

72. Wisniewski, M., Webb, R., Balsamo, R., Close, T. J., Yu, X.-M., and Griffith, M. 1999. Purification, immunolocalization, cryoprotective, and antifreeze activity of PCA60: A dehydrin from peach (Prunus persica). Physiol. Plant. 105:600-608

73. Wyatt, S., Pan, S., and Kuc. J. 1991. $\beta-1,3-$ Glucanase, chitinase and peroxidase activities in tobacco tissues resistant and susceptible to blue mould as related to flowering, age and sucker development. Physiol. Mol. Plant Pathol. 39:433-440.

74. Yu, X., Ekramoddoullah, A. K. M., and Misra, S. M. 2000. Characterization of Pin $m$ III cDNA in western white pine. Tree Physiol. 20:663671.

75. Zamani, A., Liu, J.-J., and Ekramoddoullah, A. K. M. 2005. Cloning and characterization of an antifungal peptide gene (Pm-AMP1) in western white pine (Pinus monticola). Can. J. Plant Pathol. 27:157-158.

76. Zamani, A. Sturrock, R. N., Ekramoddoullah, A. K. M., Liu, J.-J., and Yu, $\mathrm{X}$. 2004. Gene cloning and tissue expression analysis of a PR-5 thaumatin-like protein in Phellinus weirii-infected Douglas-fir. Phytopathology 94:1235-1243.

77. Zamani, A., Sturrock, R. N., Ekramoddoullah, A. K. M., Wiseman, S. B., and Griffith, M. 2003. Endochitinase activity in the apoplastic fluid of Phellinus weirii-infected Douglas-fir and its association with over wintering and antifreeze activity. For. Pathol. 33:299-316.

78. Zhu, B., Chen, T. H., and Li, P. H. 1996. Analysis of late-blight disease resistance and freezing tolerance in transgenic potato plants expressing sense and antisense genes for an osmotin-like protein. Planta 198:70-77. 